\title{
CHOICE OF LAW: A WELL-WATERED PLATEAU
}

\author{
Robert A. LeFLAR*
}

American decisional law on choice of law in conflicts cases has arrived at a level of stability, perhaps unsteady and impermanent yet very real, the like of which has not existed in the area for many years. It is a stability to be found in the opinions of appellate courts, not in the law reviews. Academic writing still stirs the ashes of recent controversy and fresh thinkers propose new approaches that might re-revolutionize the law. That is the privilege and the function of active legal minds. But most courts deciding choice-of-law cases have now settled down on a sort of policy plateau which is well above the level of Bealian conceptualism and which, though watered by the life-giving insights of American conflicts scholars among whom David F. Cavers stands out pre-eminently, does not conform in its features to the maps previously publicized by any one of them.

Analysis of opinions handed down within the last year reveals no truly new developments, no changes in the terrain but rather a smoothing over of the plateau's surface. There are still states that repeat the old mechanical rules, ${ }^{1}$ but there are fewer of them. Most of the current cases follow a pattern of multiple citation, seldom relying solely upon any single modern choice-oflaw theory, but combining two or more of the theories to produce results which, interestingly, can be sustained under any or nearly all of the new non-mechanical approaches to conflicts law.

There are fewer choice-of-law cases reported in the advance sheets nowadays than there were a few years ago, despite the fact that the total number of all reported cases has steadily increased. The current appellate cases either typify another state's breakaway from the old mechanical rules represented generally by the first conflicts Restatement ${ }^{2}$ or come from states which, having already rejected the old rules, are still fumbling among the newer approaches favored by academic commentators. Some states are engaged in more fumbling than are others. Those that fumble least achieve their stability by lumping most of the recent commentators together, taking their differences less

\footnotetext{
* Distinguished Professor of Law, University of Arkansas; Professor of Law, New York University. Author, American Conflicts Law (3d ed. 1977).

1. See, e.g., Read v. Baker, 430 F. Supp. 472, 476 (D. Del. 1977) (applying Delaware's unchanged lex loci delicti rule in a slander case); Babcock v. Maple Leaf, Inc., 424 F. Supp. 428, 431-33 (E.D. Tenn. 1976) (Tennessee's unchanged lex loci delicti rule); Ellington v. Tolar Constr. Co., 235 S.E.2d 729, 733 (Ga. App. 1977) (lex loci delicti).

2. Restatement of Conflict of Laws (1934).
} 
seriously than do the academic theoreticians. Their judicial opinions tend to speak simply of the "new" law of choice of law as distinguished from the "old," and to conclude that results arrived at can be supported by citation to the work of just about any of the conflict-of-laws writers who have proposed new ways to solve the old problems.

The average American appellate court today is handling more cases, including complex cases as well as a mass of less significant ones, than our courts have ever before had to adjudicate. Despite judicial education programs and aid from research assistants, appellate judges have less opportunity for study and broad-based inquiry than did judges in times past. The bulk of published material on all aspects of law, and especially of articles in the legal periodicals, is such that no human being can keep up with all of it, or even read in a week's time all the writing that is relevant to any one of the twentyfive or more cases an appellate judge has to pass on in the course of a typical month.

It is a fair guess that no American judge, trial or appellate, has read anything like all of the useful writing on conflict of laws that a specialized conflicts teacher must be familiar with. Much of this writing has appeared since the judge was in law school. An able and conscientious judge can cite Cavers' great book, The Choice-of-Law Process, some of Brainerd Currie's and Ehrenzweig's work, and a scattering of other writings, but that is about all. Even the hardest working student in a law school conflicts course could not read all of the "literature" on the subject, if he were taking three or four other law courses at the same time. The most that an average appellate judge working on a choice-of-law case could do would be to study an overall analysis and then read up on approaches that appealed to him. If his court had already handed down cases that broke with old concepts he would try to accommodate his thinking to those cases and would hope they fitted in with later approaches used in other states. He would cite leading cases from other states if they support his conclusion in the case before his court regardless of whether they employ the same theoretical reasoning that his court uses. The common feature of all the cases cited and the one being currently decided would be, quite often, simply the rejection of lex loci delicti, or lex solutionis, or some similar formula. Beyond that, analysis of governmental interests, dominant contacts, most significant relationships, principles of preference, choice-influencing considerations, and (often but not always) preference for the forum's own law would all ordinarily lead to the same conclusion as to who should win the case. Only states like New York ${ }^{3}$ would be so bedeviled by opposing academic theories that, attempting analytical integrity, they would let results be much affected by shifting from one modern approach to

3. See cases cited notes 53-59 infra. 
another. Most courts do not have time, or take time, for such nice distinctions, though a few, after preliminary fumblings, have adopted some one definite approach and have stuck with it.

Wisconsin illustrates the experience of states which, dissatisfied with old formulas, eventually adopted one and one only of the competing modern approaches. In 1931, in Buckeye $\%$. Buckeye, ${ }^{4}$ with a Wisconsin wife suing her husband for negligent tort committed in Illinois, the court adhered firmly to lex loci delicti, and denied recovery. In 1959 the same fact situation was recharacterized as a family law, not a tort, problem, so that recovery was allowed under Wisconsin domiciliary law. ${ }^{5}$ Then in 1965 the old approach, under which characterization was the principal source of flexibility, was abandoned, and a combination of "dominant contacts" and "governmental interest" was employed to justify recovery under Wisconsin law for a Nebraska host-guest automobile injury. ${ }^{6}$ Two years later the Wisconsin court settled upon a "choice-influencing considerations" approach" which it has consistently followed since that time. ${ }^{8}$ It is noteworthy, however, that the actual results reached in the Wisconsin cases since 1967 might in each case have been arrived at, perhaps with less emphasis upon the court's real reasons for decision, under a flexible comparison-of-governmental interests or significance-ofrelationships technique. The inexactness of these techniques would permit a court to reach any result that might be reached under Wisconsin's choiceinfluencing considerations. Similarly, a series of "principles of preference" might be discovered under the Wisconsin approach, though the "principles," once developed, ${ }^{9}$ would allow less flexibility for future cases than would the other techniques.

Essentially the same potentialities inhere in the results reached by the courts of other states, such as New Hampshire, ${ }^{10}$ Rhode Island, ${ }^{11}$ and Minnesota, ${ }^{12}$ that have adopted the "choice-influencing considerations" ap-

4. 203 Wis. 248,234 N.W. 342 (1931).

5. Haumschild v. Continental Casualty Co., 7 Wis. 2d 130, 95 N.W.2d 814 (1959). The family law characterization produced an unsatisfactory result, however, in the next case, Haynie v. Hanson, 16 Wis. 2d 299, 114 N.W.2d 443 (1962), in which recovery had to be denied under Illinois domiciliary law in a husband-wife action for Wisconsin injury.

6. Wilcox v. Wilcox, 26 Wis. 2d 617, 633-35, 133 N.W.2d 408, 416-17 (1965).

7. Heath v. Zellmer, 35 Wis. 2d 578, 596, 151 N.W.2d 664, 672 (1967).

8. Lichter v. Fritsch, __ Wis. $2 \mathrm{~d} \ldots, 252 \mathrm{~N}$.W.2d 360 (1977) (differing rules as to effect of leaving keys in ignition of auto then stolen and driven negligently, injuring plaintiff); Hunker v. Royal Indemnity Co., 57 Wis. 2d 588, 204 N.W.2d 897 (1973) (variety of tort issues, Ohio law applied); Haines v. Mid-Century Ins. Co., 47 Wis. 2d 442, 177 N.W.2d 328 (1970) (contracts case).

9. That method for developing "principles of preference" would not be greatly different from that illustrated in D. Cavers, The Choice-of-Law Process 139, 181 (1965).

10. See Maguire v. Exeter \& Hampton Elec. Co., 114 N.H. 589, 325 A.2d 778 (1974); Clark v. Clark, 107 N.H. 351,222 A.2d 205 (1966).

11. See Brown v. Church of the Holy Name of Jesus, 105 R.I. 322, 252 A.2d 176 (1969); Turcotte v. Ford Motor Co., 494 F.2d 173 (1st Cir. 1974) (applying Rhode Island conflicts law).

12. See Myers v. Govt. Employees Ins. Co., 225 N.W.2d 238 (Minn. 1974); Milkovich v. Saari, 
proach for their choice-of-law cases. The decisions give honest reasons for their results, though the same results might have been reached with equal logic and less explanation of underlying reasons by employing any of the other currently publicized approaches to the choice-of-law process.

A number of recent cases mix the several modern approaches together. Wallis \%. Mrs. Smith's Pie Co. ${ }^{13}$ is typical. The plaintiff was an Arkansas resident returning to Arkansas from a motor trip to Ohio. While crossing Missouri on an interstate highway deeply covered with ice and snow, he drove on the left, or inside, lane. A Missouri statute required driving on the right, or outside, lane at all times except when passing other vehicles. Defendant was a Pennsylvania corporation whose truck was being driven from Pennsylvania to Oklahoma. As the truck approached plaintiff's car from behind it was moved from the outside to the passing lane, but due to the ice and snow it was not brought under control at once and rammed the back end of plaintiff's slower-moving car, causing the injuries complained of. Defendant's driver was clearly negligent, but by Missouri law plaintiff was negligent also, because he was violating the Missouri statute by driving in the wrong lane. By Missouri law plaintiff's contributory negligence barred all recovery. The Arkansas comparative negligence statute would permit a proportional recovery if plaintiff's negligence was less than defendant's. Service on defendant in Arkansas was good since it was a foreign corporation doing business in the state with a local agent authorized to receive service.

The Arkansas Supreme Court, speaking through Justice Elsijane T. Roy, first indicated that its earlier lex loci delicti decisions ${ }^{14}$ were no longer controlling. It then analyzed the facts in the light of five choice-influencing considerations, concluding: ${ }^{15}$

We therefore find that this state has a predominant interest in applying its comparative fault statutes to its own citizens and those who seek relief in its courts. ... For equally compelling reasons we find Missouri rules of the road are applicable to questions of alleged negligence in the actual driving of the vehicle. At the time of the accident, the parties were traveling the highways of Missouri and were under a duty to obey the traffic laws in force there.

Though the choice-influencing considerations were relied upon, ${ }^{16}$ they were by no means the sole support for the decision. ${ }^{17}$

295 Minn. 155, 203 N.W.2d 408 (1973); Meyer v. Chicago, R.I. \& Pac. R.R., 508 F.2d 1395 (8th Cir. 1975) (applying Minnesota conflicts law).

13. 261 Ark. 622,550 S.W.2d 453 (1977)

14. See Bell Transp. Co. v. Morehead, 246 Ark. 170, 437 S.W.2d 498 (1969); McGinty v. Ballentine, 241 Ark. 533, 408 S.W.2d 891 (1966).

15. 550 S.W.2d at 458 .

16. Cited cases which employed that basis for decision included Schwartz v. Consolidated Freightways Corp., 300 Minn. 487, 221 N.W.2d 665 (1974); Clark v. Clark, 107 N.H. 351,222 A.2d 205 (1966); and Woodward v. Stewart, 104 R.I. 290, 243 A.2d 917 (1968).

17. Had the Missouri accident occurred after September 7, 1976 a strengthened basis for the conclusion that a comparative negligence rule governed would have been available. Pennsylvania's 
The other-state decision principally relied upon was Mitchell $v$. Craft, ${ }^{18}$ from Mississippi. The problem in that case was somewhat similar, involving an auto collision in Louisiana between Mississippi parties driving Mississippi cars, with evidence of negligence in both parties. The decision was that Mississippi's comparative negligence rule, rather than the Louisiana strict rule of contributory negligence, should govern the parties' rights. The court's reasoning combined the five choice-influencing considerations and the "most significant relationship" approach of the Restatement (Second) of Conflict of Laws, ${ }^{\mathbf{1 9}}$ with an emphasis upon Mississippi's governmental interest in the issue. As in the Arkansas case, reliance was on no single one of the modern choice-of-law approaches.

The breadth of the Arkansas court's reasoning is further indicated by its reliance on Babcock $v$. Jackson, ${ }^{20}$ which applied the early "dominant contacts" test to choice of law in an automobile accident case, and on Sabell $v$. Pacific Intermountain Express Co. ${ }^{21}$ a Colorado-Iowa case involving comparative and contributory negligence in which the approach followed was the second Restatement's "most significant relationship" analysis. The opinion is similar to others which have combined the choice-influencing considerations approach with Restatement (Second)'s most significant relationship and with Brainerd Currie's governmental interest analysis to explain results supported by each technique. ${ }^{22}$

A Missouri case ${ }^{23}$ also illustrates the diversity. The action was on a liability insurance policy issued in Missouri to the plaintiff's decedent, a Missouri domiciliary. A clause in the policy provided for payment of all sums to which

comparative negligence rule, Pa. Stat. Ann. tit. 17, \$§ 2101,2102 (5 Pa. Leg. Serv. 1976), quite similar to the Arkansas statute, took effect on the later date. It was not retroactive. Sherman, $A n$ Analysis of Pennsylvania's Comparative Negligence Statute, 38 U. PITT. L. Rev. 51, 62 (1976). Had it been in effect, it would have had relevance to the conduct of a Pennsylvania defendant. The combined relationship of Arkansas and Pennsylvania to the case would have made the ArkansasPennsylvania law clearly controlling as against the Missouri law, on that issue. R. LEFLAR, American Conflicts Law 237 (1968); Leflar, True "False Conflicts" et Alia, 48 B.U. L. Rev. 164 (1968); Westen, False Conflicts, 55 Calif. L. REv. 74 (1967); accord, Pfau v. Trent Aluminum Co., 55 N.J. 511, 263 A.2d 129 (1970) (ordinary negligence law of New Jersey and Connecticut applied as against host-guest statute of lowa where injury occurred). See also cases cited note 75 infra.

18. 211 So. 2d 509 (Miss. 1968).

19. Quoting $\$ \S 145,164,175$ and the basic $\S 6$ (1971). See Wright v. Standard Oil Co., 470 F.2d 1280 (5th Cir. 1973) (applying Mississippi conflicts law as based upon a combination of significant relationships and choice-influencing considerations).

20. 12 N.Y.2d 473, 191 N.E.2d 279, 240 N.Y.S.2d 743 (1963).

21. 36 Colo. App. 60, 536 P.2d 1160 (1975).

22. E.g., Fuerste v. Bemis, 156 N.W.2d 831 (Iowa 1968); Beaulieu v. Beaulieu, 265 A.2d 610 (Me. 1970); Kennedy v. Dixon, 439 S.W.2d 173 (Mo. 1969).

23. Byrn v. American Universal Ins. Co., 548 S.W.2d 186 (Mo. App. 1977). For a case describing comparable diversity under Louisiana conflicts law, see Ardoyno v. Kyzar, 426 F. Supp. 78 (E.D. La. 1976) (inducing breach of contract; slander). 
the insured "shall be legally entitled" as damages from an uninsured motorist. ${ }^{24}$ The decedent was injured, then died, as a result of the ordinary (not reckless or wanton) negligence of an uninsured Iowa motorist with whom she was riding as a guest on a wholly Iowa trip. Missouri had no guest statute, but Iowa did. The 2-1 majority of the Missouri Court of Appeals used a tort characterization in holding that Iowa law governed so that the decedent was not "legally entitled" to recover from her Iowa host. The reasoning was a combination of Restatement (Second)'s "most significant relationship" analysis and comparison of the "interests" of the two states, plus an explanation that Missouri's "better law" could not be used since, among other reasons, Missouri had inadequate contacts with the tort.

The dissent would have achieved application of Missouri's ordinary negligence rule by characterizing the problem as one of interpreting a Missouri insurance contract, as interpretation would be under Missouri law. It was an interesting effort, reminiscent of an earlier conflicts era, to use characterization as a gimmick for the purpose of enabling a court to apply what it regarded as the "better law" to the set of facts. ${ }^{25}$

Massachusetts in 1976 achieved a graceful breakaway from the old lex loci delicti rule. In Pevoski v. Pevoski, ${ }^{26}$ a Massachusetts wife sued her Massachusetts husband for injuries suffered in New York by reason of his negligent driving there. The holding was that the case was governed by a newly interpreted Massachusetts common law rule under which a wife may recover in tort from her husband. ${ }^{27}$ For the Supreme Judicial Court, Reardon, J., wrote: ${ }^{28}$

In this Commonwealth, lex loci delicti has been firmly established as the general tort conflicts rule. ... This rule has provided, and will continue to provide, a rational and just procedure for selecting the law governing the vast majority of issues in multistate tort suits. For example, in motor vehicle torts such as the one at bar standards of negligence will be appropriately furnished by the law of the jurisdiction in which the accident occurred. Rules of the road are determined quite properly by the State in which the roads are located-by the jurisdiction having the strongest interest in regulating the conduct of drivers on these highways.

But we recognize that there also may be particular issues on which the

24. 548 S.W.2d at 187.

25. See generally Grant v. McAuliffe, 41 Cal. 2d 859, 264 P.2d 944, 42 A.L.R.2d 1162 (1953); Levy v. Daniels' U-Drive Auto Renting Co., 108 Conn. 333, 143 A. 163, 61 A.L.R. 646 (1928); Kilberg v. Northeast Airlines, Inc., 9 N.Y.2d 34, 172 N.E.2d 526 (1961); Dyke v. Erie Ry. Co., 45 N.Y. $113(1871)$.

26. 358 N.E.2d 416 (Mass. 1976).

27. Interestingly, the new interpretation of Massachusetts husband-wife law made it the same as New York law, so that there was no conflict between the laws of the two states. Compare note 17 supra. It was nevertheless understandable that the court should seize the opportunity to update its obsolete conflicts rule.

28. 358 N.E.2d at 417 . 
interests of lex loci delicti are not so strong . . . another jurisdiction may sometimes be more concerned and more involved with certain issues than the State in which the conduct occurred. . . In this instance the economic and social impact of this litigation will fall on Massachusetts domiciliaries and a Massachusetts insurer. New York has an undoubted interest in enforcing its traffic laws and in making its highways safe for travel but it has no legitimate interest in regulating the interspousal relationships of Massachusetts domiciliaries who chance to be injured within its borders.

It must be noted that, in addition to its sound comparison of the governmental interests of the two states on the separate issues, the opinion relied upon Babcock ข. Jackson ${ }^{29}$ which was a "dominant contacts" decision and also cited Chief Justice Kenison's opinion in Clark v. Clark ${ }^{30}$ which initiated the choiceinfluencing considerations approach to choice-of-law decision.

An odd variation from the Massachusetts husband-wife problem is presented by a North Carolina case. ${ }^{31}$ Pennsylvania spouses were driving in North Carolina where the wife was injured by the husband's negligence. North Carolina allowed a wife to sue her husband in tort; Pennsylvania did not. North Carolina had long followed the lex loci delicti rule, but the North Carolina legislature in 1967 made a partial change in it, prescribing that North Carolina spouses should be allowed to recover from each other under North Carolina law for injuries inflicted in other states. The statute said nothing about interspousal torts inflicted in North Carolina between nondomiciliaries, the case now before the court. The decision was that the lex loci delicti still applied to such local injuries, thus permitting interspousal recovery under North Carolina law in both situations. There was no suggestion in the opinion that the result might have been tacitly motivated by a belief that North Carolina's liberal recovery rule was the "better law."

Federal cases from New Jersey illustrate the judicial tendency to employ more than one approach to support a particular result. Federal courts sitting in New Jersey of course undertook to apply New Jersey conflicts law, which in general relies upon a comparison of governmental interests of the affected states. $^{32}$

In one case, ${ }^{33}$ the New Jersey action was by a New Jersey plaintiff to enjoin a Georgia defendant from disparagement of the plaintiff's commercial product. The alleged disparagement was occurring in Nebraska, Illinois, Michigan, Delaware, and New Jersey. The court recognized that each of these five states, and possibly Georgia as well, had a "substantial interest in having its law applied," but concluded that it was impractical to apply the disparage-

\footnotetext{
29. 12 N.Y.2d 473, 191 N.E.2d 279, 240 N.Y.S. 743 (1903). Also see text at note 20 supra.

30. 107 N.H. 35 I, 222 A.2d 205 (1966). See text at note 10 supra.

31. Henry v. Henry, 291 N.C. 156, 229 S.E.2d 158 (1976).

32. Pfau v. Trent Aluminum Co., 55 N.J. 511,263 A.2d 129 (1970); Mellk v. Sarahson, 49 N.J. 226, 229 A.2d 625 (1967).

33. System Operations v. Scientific Games Dev. Corp., 555 F.2d 1131 (3d Cir. 1977).
} 
ment laws of each state separately to the facts in which that state was interested. The answer was to apply New Jersey's, the forum's, law to the entire set of facts. In doing this, the court employed governmental interest analysis, most significant relationships as set out in the Restatement (Second), and enumerated policy considerations, but relied mostly upon the practicalities of the situation.

In the other case,$^{34}$ the question was as to the measure of damages recoverable in survived causes of action for injuries suffered in New Jersey by Pennsylvania decedents, as against defendants who were residents of New Jersey or doing business there. The New Jersey measure of damages was appreciably lower than Pennsylvania's. It was agreed that measure of damages is a substantive issue, not merely procedural. ${ }^{35}$ The court's comparison of governmental interests identified interests in both New Jersey and Pennsylvania, a "true conflict" of governmental interests. ${ }^{36}$ To reach its decision, favoring the lesser damages given by New Jersey law, the court relied upon both Brainerd Currie's preference for forum law ${ }^{37}$ and Cavers' second "principle of preference," 38 while at the same time indicating potential applicability of a "better law" approach which, though not immediately controlling, was said to be relevant to slightly different facts. ${ }^{39}$ Substantial consistency, and no incon-

34. Colley v. Harvey Cedars Marina, 422 F. Supp. 953 (D.N.J. 1976). A later New Jersey state case, Wuerffel v. Westinghouse Corp., 148 N.J. Super. 327, 372 A.2d 659 (1977) again illustrates that state's pluralism. On a question of corporate charitable immunity in tort, the conclusion was that the law of Pennsylvania, which denied immunity, rather than New Jersey law, which would allow immunity, should govern. The plaintiff, injured in New Jersey, was a New Jersey resident, but the defendant was a Pennsylvania non-profit corporation. The court's reasoning combined governmental-interest, most-significant-relationships, and grouping-of-contacts approaches, but did not mention a preference for the modernized Pennsylvania rule under which the injured resident of the forum state could recover against the foreign corporation.

35. Accord, Davenport v. Webb, 11 N.Y.2d 892, 183 N.E.2d 902, 230 N.Y.S.2d 17 (1962), rejecting the procedural characterization employed in Kilberg $v$. Northeastern Airlines, Inc., 9 N.Y.2d 34, 172 N.E.2d 526, 211 N.Y.S.2d 1133 (1961).

36. $C f$. note 17 supra (dealing with conflict of laws as distinguished from conflict of governmental interests).

37. Currie, Notes on Methods and Objectives in the Conflict of Laws, 1959 DukE L.J. 171, 177, reprinted in B. Currie, Selected Essays on the Conflict of Laws 177, 183 (1963).

38. "Where the liability laws of the state in which the defendant acted and caused an injury set a lower standard of conduct or of financial protection than do the laws of the home state of the person suffering the injury, the laws of the state of conduct and injury should determine the standard of conduct or protection applicable to the case, at least where the person injured was not so related to the person causing the injury that the question should be relegated to the law governing the relationship." D. CAVERs, supra note 9, at 146 (1965).

39. 422 F. Supp. at 957 n.10, in part states: "R.A. Leflar suggests that a court should apply the 'better rule of law' (citation). This sentiment is also expressed by von Mehren and Trautman in their espousal of a functional approach to true conflicts. A. von Mehren \& D. Trautman, The Law of Multistate Problems $76-79$ (1965). Under this theory, a court should apply an emerg. ing rather than a regressive policy (citation). If this case involved recovery for wrongful death, the choice of Pennsylvania law as the more enlightened approach would be appealing. However, in the context of a survival action the purpose of which has been held to be protection of creditors, . . . we do not feel that Pennsylvania law should be preferred to that of New Jersey." 
sistency, appeared from the court's recognition of the three approaches.

A comparable fact situation, also involving a measure-of-damages issue but with the opposite conclusion, was presented by an Illinois federal case ${ }^{\mathbf{4 0}}$ handed down three weeks earlier. The plaintiff, an Illinois resident, was injured in Mozambique, an African territory then a colony of Portugal, by the negligence of an employee of defendant, a Mozambique corporation under whose guidance plaintiff was engaged in an African safari. Preliminary negotiations for the trip had taken place in Illinois but, said the court, the parties' relationship "can fairly be characterized as centering in Mozambique." ${ }^{4}$ As in the New Jersey case, the damages allowable by the law of the place of injury and the defendant's domicile (Mozambique) would be substantially less than those allowable under the law of the plaintiff's residence (Illinois). Illinois conflicts law, ${ }^{42}$ which the federal court undertook to apply, follows the Restatement (Second) of Conflict of Laws' 'most significant relationship" approach, ${ }^{43}$ though the federal court in restating it quite understandably used some of the language of governmental interest ${ }^{44}$ as well. The court said that the facts presented a "true conflict" (of governmental interests). Then, relying primarily on a New York federal case ${ }^{45}$ which had analyzed relevant choice-influencing factors, the court held that the more liberal Illinois damages rule should govern because the restrictive rule of Portuguese Mozambique "contravenes a sound public policy of the forum." 46 This is essentially a Brainerd Currie "forum preference"47 decision with "better law" overtones, though it attempts to follow the Illinois "most significant relationships" conflicts rule.

Another damages case, ${ }^{48}$ different both in its facts and in the explanation of its conclusion, comes from Washington. The action was by a Kansas widow for the wrongful death of her Kansas husband in Kansas, in the course of his use in his Kansas cleaning business of an allegedly defective scaffolding manufactured in Washington by defendants' Washington corporations and shipped

40. Pancotto v. Sociedade de Safaris de Mocambique, S.A.R.L., 422 F. Supp. 405 (N.D. Ill. 1976).

41. 422 F. Supp. at 408 .

42. See, e.g., Ingersoll v. Klein, 46 Ill. 2d 42, 262 N.E.2d 593 (1970); Velle Transcendental Research Ass'n Inc. v. Esquire, Inc., 41 Ill. App. 3d 799, 354 N.E.2d 622 (1976) (defamation, "most significant contacts" rule).

43. §145 (1971).

44. "Finally, under the Illinois choice-of-law rule, the law of the state or country of the place of injury is followed, unless Illinois is more significantly interested in the resolution of a particular issue." $422 \mathrm{~F}$. Supp. at 407 (Italics added.)

45. Rosenthal v. Warren, 475 F.2d 438 (2d Cir. 1973). On this case, see discussion in text at note 59 infra.

46. 422 F. Supp. at 412 .

47. Currie, supra note 37 , at 177.

48. Johnson v. Spider Staging Corp., 87 Wash. 2d 577, 555 P.2d 997 (1976). The Washington cases prior to this decision are discussed in Powers, Formalism and Nonformalism in Choice of Law Methodology, 52 WASH. L. REv. 27 (1976). 
by them from Washington to him in Kansas after he ordered it through defendants' Kansas City distributor. Kansas had a $\$ 50,000$ top limit on wrongful death recoveries, while Washington had no top limit. The decision was that the Washington law should govern. Washington was already committed, and remained committed, to the Restatement (Second)'s "most significant relationship" approach to choice of law, ${ }^{49}$ though with corollary reference to "consideration of the interests and public policies of potentially concerned states"50 and a substantial emphasis on the choice-influencing factors enumerated in the Restatement's $\S 6$. It was evident that the court regarded Washington's rule as the better law. The reasoning was summed up: $:^{51}$

\begin{abstract}
Each state has a distinct relationship with this cause, and the contacts are evenly balanced. ... A state's interest in limiting wrongful death damages is to protect defendants from excessive financial burdens. . . Kansas has no interest in applying its limitation to nonresident defendants being sued in their home state, and Washington has a legitimate interest in the application of its law.
\end{abstract}

It might be added that Washington's governmental interests, as they appeared from this opinion, were those of a justice-dispensing court in a modern American state, a repository of justice not only for the benefit of home-state domiciliaries but for all litigants who come before the court, even residents of distant states, and even as against local persons. ${ }^{52}$

That attitude contrasts rather sharply with some of the recent New York decisions. That state's early approval of the "dominant contacts" approach, in Auten $v$. Auten ${ }^{53}$ and Babcock v. Jackson,,$^{54}$ gave initial impetus to the choice-oflaw revolution that followed, but the inexactness of that initial approach and the room it left for difference of opinion as to what contacts were dominant (most significant) produced inevitable confusion in the later cases. ${ }^{55}$ A major difficulty was judicial unwillingness to identify and admit the existence of choice-influencing considerations that were not explicit in the analysis of dominant contacts alone, yet which exerted influence on the actual conclusions reached by the judges. A gradual shift by most of the New York court to a comparison of governmental interests ${ }^{56}$ did not eliminate the confusion, be-

49. Werner v. Werner, 84 Wash. 2d 360, 526 P.2d 370 (1974); Baffin Land Corp. v. Monticello Motor Inn, Inc., 70 Wash. 2d 893, 425 P.2d 623 (1967). See [P.] Trautman, Eıolution in Washington Choice of Law, 43 WASH. L. REv, 309 (1967).

50. Potlatch No. 1 Federal Credit Union v. Kennedy, 76 Wash. 2d 806, 810, 459 P.2d 32,35 (1969).

51. 87 Wash. 2d at 582-84, 555 P.2d at 1001-02.

52. But cf. R. Leflar, American Conflicts Law 252-54 (1968).

53. 308 N.Y. 155,124 N.E.2d 99 (1954) (contracts).

54. 12 N.Y.2d 473,191 N.E.2d 279,240 N.Y.S.2d 743 (1963) (tort).

55. E.g., the differing views expressed in Dym v. Gordon, 16 N.Y.2d 120, 209 N.E.2d 792. 262 N.Y.S.2d 463 (1965) and Tooker v. Lopez, 24 N.Y.2d 569, 249 N.E.2d 394, 301 N.Y.S.2d 519 (1969). Cf. Kell v. Henderson, 26 App. Div. 2d 595, 270 N.Y.S.2d 552 (3d Dept. 1966).

56. Miller v. Miller, 22 N.Y.2d 12, 237 N.E.2d 877, 290 N.Y.S.2d 734 (1968). 
cause this approach was too inexact, identifying incompletely the real reasons for some decisions.

The current New York position is exemplified by two decisions, one from the New York Court of Appeals and the second, undertaking to apply New York conflicts law, from the United States Court of Appeals for the Second Circuit.

Neumeier v. Kuehner ${ }^{57}$ is the state court case. It was an action brought for the death of an Ontario resident while a guest in Ontario in a New Yorker's auto. The death was caused by the New Yorker's ordinary, not gross, negligence. Ontario's guest statute would preclude recovery from the host; New York's ordinary negligence rule would allow recovery. The Appellate Division thought that under the previous cases the New York ordinary negligence rule would be applied, but the Court of Appeals held for the defendant. The decisive facts were that the driver was a resident of New York and the plaintiff's decedent was a nonresident. The opinion, expressed in terms of the forum state's governmental interests, asserted that New York had no interest in applying its more plaintiff-protective rule against one of its own residents in favor of a person from another state or country whose own law would not give him the greater protection. New York's governmental interests were made to coincide with the interests of its residents, as against nonresidents. The result and the reasoning were exactly opposite to those in the Washington case, ${ }^{58}$ on basically similar facts.

The self-centered nature of the New York position is emphasized by Rosenthal $v$. Warren ${ }^{59}$ the slightly later diversity case in which the Second Circuit attempted to apply the New York law as it was laid down in Neumeier. As to the choice-of-law problem, the cases were similar, except that the facts as to residence of the parties were turned around. The decedent for whose wrongful death the action was brought was a resident of New York and the defendant was a Massachusetts doctor whose alleged malpractice in a Massachusetts hospital had caused the decedent's death in the latter state. The question was whether the Massachusetts top limit on recovery, or the New York no-toplimit rule, should be applied. ${ }^{60}$ The Second Circuit's conclusion was that the New York court would apply its own plaintiff-protective rule in favor of the local plaintiff. The existence of a dominant New York governmental interest turned on the fact that the plaintiff, or his decedent, was a New Yorker. The

57. 31 N.Y.2d 121, 286 N.E.2d 454, 335 N.Y.S.2d 64 (1972).

58. Johnson v. Spider Staging Corp., 87 Wash. 2d 577, 555 P.2d 997 (1976); text at notes 48-52 supra.

59. 475 F.2d 438 (2d Cir. 1973).

60. The idea that measure of damages is a procedural, not substantive matter, Kilberg $v$. Northeast Airlines, Inc., 9 N.Y.2d 34, 172 N.E.2d 526, 211 N.Y.S.2d 133 (1961), rejected in Davenport v. Webb, 11 N.Y.2d 392, 183 N.E.2d 902 (1962), was not relied upon in reaching the decision. 
effect was that, with reference to an extrastate tort involving a nonresident and a New York party, the New Yorker, whether plaintiff or defendant, would win in each case on the analysis that New York's governmental interest favored its own citizens. An argument might be made that this amounts to a denial of equal protection of the laws to nonresident persons within the jurisdiction. At least it contradicts the ideal of a state's legal system as a repository of justice for residents and nonresidents alike, an ideal which should inhere in the governmental interests of any state. Unwillingness to take account of the better rule of law as a choice-influencing consideration seems strange indeed in the light of this preference for the litigant who is locally regarded as the "better party" because his home is in the forum state. ${ }^{61}$

It seems that New York's law of choice of law, currently more unsatisfactory than that of any other state that has moved away from lex loci delicti and similar old rules, will have to be further modified, as undoubtedly it will be, before it can fairly be listed among the states that have achieved a reasonable flexibility under modern conflicts theories.

Two current dramshop cases, both imposing liability on defendants who in a first state sold liquor to intoxicated autoists who then in adjacent states drunkenly injured the respective plaintiffs, afford an interesting theoretical contrast. In Bernhard v. Harrah's Club,$^{62}$ the sale of liquor was in Nevada to a Californian who then drove across the nearby state line into California where his drunken driving injured the California plaintiff. California law would impose liability on a liquor seller; Nevada law would not. Employing the comparison-of-governmental interests approach which has been accepted in California, ${ }^{63}$ the Supreme Court of that state concluded that though both states had real interests in the matter, there would be less "comparative impairment"64 of Nevada's interests if its law were disregarded than there would be of California's interests if Nevada's no-liability law were applied. Thus the plaintiff won under the dramshop act of the forum state, the place of the accident

61. A question may be raised as to whether it is correct to attribute a "local litigant as the better party" consideration to New York interest analysis, since the court does not say that this is its reasoning, but only reaches that result and explains it in more abstract language.

62. 16 Cal. 3d 313, 546 P.2d 719, 128 Cal. Rptr. 215 (1976).

63. Hurtado v. Superior Court, 11 Cal. 3d 574, 522 P.2d 666, 114 Cal. Rptr. 106 (1974); Reich v. Purcell, 67 Cal. 2d 551, 432 P.2d 727, 63 Cal. Rptr. 31 (1967).

64. The "comparative impairment" method of comparing the governmental interests of states between whose laws a choice must be made was proposed in Baxter, Choice of Law and the Federal System, 16 Stan. L. Rev. 1 (1963). See Beech Aircraft Corp. v. Superior Court, 61 Cal. App. 3d 501, 132 Cal. Rptr. 541 (1976) (forum law preferred as against law of New Mexico, on "comparative impairment" reasoning). Compare Offshore Rental Co. v. Continental Oil Co., 70 Cal. App. 3d 502, 138 Cal. Rptr. 838 (1977), in which the holding, where both California and Louisiana had "governmental interests" in a tort liability issue, was that application of other-state law would impair Louisiana's interests more than California's, so that the Louisiana law denying tort liability was applied, though the plaintiff was a California corporation and the defendant a Louisiana corporation. 
and of his domicile. It is a fair guess that if a Nevada court had applied the same reasoning to the same set of facts it would have decided to apply Nevada's law. "Comparative impairments," like comparison of interests, can produce differences of judicial opinion.

In the other case, ${ }^{65}$ Minnesota residents sued an Iowa liquor seller in Iowa for injuries suffered in Minnesota in an automobile accident allegedly caused by defendant's sale of liquor in Iowa to the driver who subsequently collided with the plaintiffs in Minnesota. Decision for the plaintiff, this time under the law of the place where the liquor was sold, was based primarily upon cited precedents from other states ${ }^{66}$ without much theoretical analysis.

The interesting result was that recovery was allowed in each case, though under the laws of states whose contacts were opposites. A good analysis of the judicial problem, directed to the California case but equally applicable to the Iowa decision, appears in a discerning Comment: ${ }^{67}$

If interest analysis has not resolved the conflict between the interests of the states, a court then ought to seek the proper solution between the parties, that is, the solution established as "just" for controversies between parties who are both residents of the forum and between whom a court has no preference ... the forum's rule. The rule provides a reasoned and predictable decision, both because it is based upon an expectation that a court will do justice and because it will assure consistency.

This does not deny that there will sometimes be cases in which justice can best be achieved by applying non-forum law, and it puts the emphasis where it belongs, on justice under the law, at the same time that it recognizes the natural judicial tendency to discover justice most readily under the local system of law with which the court is familiar.

Statute-of-limitations questions, once normally characterized as procedural and governed by forum law, ${ }^{68}$ are now increasingly freed from that mechanical mold and handled as are other choice-of-law issues that directly affect the outcome of litigation. New Jersey, with its variations on comparison-of-state-

65. Bankford v. DeRock, 423 F. Supp. 602 (N.D. Iowa 1976). Compare Anderson v. Luitjens, 247 N.W.2d 913 (Minn. 1976) (Minnesota long-arm jurisdiction sustained over Iowa liquor seller whose drunken buyer-driver caused injuries in Minnesota, on assumption that bordertown tavern keeper was liable under Minnesota law') with Schmidt v. Driscoll Hotel, Inc., 249 Minn. 376, 82 N.W.2d 365 (1957) (relied upon in Bankford, in which Minnesota held that its dramshop act applied to Minnesota liquor sales causing injuries in Wisconsin). The local law is thus deemed applicable in both situations.

66. Trapp v. 4-10 Investment Corp., 424 F.2d 1261 (8th Cir. 1970) (North Dakota conflicts law); Zucker v. Vogt, 200 F. Supp. 340 (D. Conn. 1961) (Connecticut conflicts law); Schmidt v. Driscoll Hotel, Inc., 249 Minn. 376, 82 N.W.2d 365 (1957).

67. Comment, After Hurtado and Bernhard: Interest Analysis and the Search for a Consistent Theory for Choice-of-Law Cases, 29 STAN. L. REv. 127, 151 (1976).

68. Steele v. G.D. Searle \& Co., 428 F. Supp. 646 (S.D. Miss. 1977) recognized the modern trend but stayed with the procedural characterization because no Mississippi state decision had yet rejected it, as did Alaska Airlines, Inc. v. Lockheed Aircraft Corp., 430 F. Supp. 134 (D. Alaska 1977), on Alaskan law. 
interests approach to choice of law, ${ }^{69}$ was a pioneer ${ }^{70}$ in rejection of the old characterization. A current case ${ }^{71}$ from that state discovers and gives effect to a New Jersey interest in applying its longer statute of limitations against a New Jersey defendant in favor of Illinois plaintiffs injured by defendant's negligence in Quebec. The forum's plaintiff-protective rule was applied against a forum resident in favor of a nonresident, the same as in the Washington case $\mathrm{e}^{72}$ previously commented upon. An Oregon case ${ }^{73}$ achieved a similar result somewhat more easily. The action was against a Washington corporation for the wrongful death of an Oregon resident suffered in a British Columbia airplane accident in the course of a trip that began and was to end in Oregon. The action would have been barred by the British Columbia oneyear statute, but on a combination of interest analysis and most-significantrelationship reasoning it was held to be still maintainable under the three-year statutes of Washington and Oregon. There was "no conflict" between the laws of the two states, ${ }^{74}$ whose combined interests and relationships clearly outweighed those of British Columbia. ${ }^{75}$ In partial contrast, the Seventh Circuit Court of Appeals, in Kalmich $v$. Bruno, ${ }^{76}$ applying the Illinois "most significant relationship" approach, ${ }^{77}$ treated limitations as a substantive matter in order to permit an action to be maintained under the longer statute of the place where the cause of action arose. The action was for misappropriation of plaintiff's assets in Yugoslavia in 1942. The Illinois statute had long since run, but the Yugoslavian statute makes claims for War Crimes, which this was alleged to be, "perpetually actionable." This language was deemed to satisfy a "specificity" test ${ }^{78}$ so that the Yugoslavian statute governed and the action could be maintained. The only common features of the New Jersey, Oregon, and Illinois cases are that in each of them procedural characterization was rejected and the longer limitations period was applied to allow the plaintiff to bring his action.

Choice-influencing considerations in contracts cases will often not operate

69. See notes 32-39 supra and accompanying text.

70. Heavner v. Uniroyal, Inc., 63 N.J. 130, 305 A.2d 412 (1973), followed in Allen v. Volkswagen of America, Inc., 555 F.2d 361 (3d Cir. 1977), and Henry v. Richardson-Merrell, Inc., 508 F.2d 28 (3d Cir. 1975), both New Jersey cases.

71. Thompson v. Yue, 426 F. Supp. 853 (D.N.J. 1977).

72. See notes 48-52 supra, and accompanying text.

73. Myers v. Cessna Aircraft Corp., 275 Ore. 501, 553 P.2d 355 (1976).

74. Cf. note 17 supra (illustrates a combined interests situation).

75. “As between Oregon/Washington and British Columbia, the only relationship which British Columbia has to this action is the entirely fortuitous event that it happened to be the site of the crash. British Columbia could, therefore, have no substantial interest in having its statute of limitations prevent the maintenance of this action." Meyers v. Cessna Aircraft Corp., 275 Ore. at $\_, 553$ P.2d at 367. Cf. Natural Resources Corp. v. Royal Resources Corp., 427 F. Supp. 880 (S.D.N.Y. 1977).

76. 353 F.2d 549 (7th Cir. 1977).

77. See cases cited note 42 supra.

78. As in Bournias v. Atlantic Maritime Co., Ltd., 220 F.2d 152 (2d Cir. 1955). 
the same as in torts cases, but the old mechanical choice-of-law rules based on contract characterization are today almost obsolete. The modern tendency is to sustain the validity of any contract made in good faith by parties in a fairly equal bargaining position if it would be validated by the law of any substantially connected state and is not contrary to the strong public policy of the forum state. This approach furthers predictability by effectuating what the parties have in good faith planned, interferes in no way with interstate or international order, is easily administered, takes account of the forum's governmental interests, and applies what for any specific facts may fairly be regarded as the better rule of law.

Current contracts cases bear out this tendency. The Nebraska court held that a promissory note made in Oklahoma with an interest rate permissible in Oklahoma but usurious by Nebraska law would be enforced in Nebraska. ${ }^{79}$ To the same effect, California enforced the higher interest rate allowed by New York law, though it would be usurious by California law, on a contract made in California, when parties equal in bargaining capacity included in their contract a provision that the law of New York, where the payee had its headquarters, should govern it. ${ }^{80} \mathrm{~A}$ federal court sitting in New York enforced a clause that English law should govern a contract under which an English plaintiff was to ship goods from England to defendants in New York. ${ }^{81}$ With the opposite result, but consistently, a West Virginia court held that a clause in a contract between New York and West Virginia parties, made and to be largely performed in West Virginia, stating that the contract should be governed by New York law and that jurisdiction was by the contract conferred upon a New York court in all actions brought on the contract, was invalid. ${ }^{82}$ The result was to deny full faith and credit to a New York default judgment rendered in favor of the New York party under the authority of the jurisdiction-conferring contract clause. The court agreed that jurisdiction-selecting clauses could be valid, ${ }^{83}$ but held that this one violated West Virginia's strong public policy and was invalid under West Virginia law because the parties were not in equal bargaining positions and enforcement of it against the West Virginia party would have caused such great inconvenience to him and his witnesses as to be unreasonable and unjust. No two of these contracts cases use identical choice-of-law reasoning, but all fit in neatly under any combination of modern choice-of-law approaches.

A different and better answer to some of the most difficult of all conflicts

79. Grady v. Denbeck, 198 Nebr. 31,251 N.W.2d 864 (1977).

80. Gamer v. duPont Walston, Inc., 65 Cal. App. 3d 280, 135 Cal. Rptr. 230 (1977).

81. Orlik Ltd. v. Helme Products, Inc., 427 F. Supp. 771 (S.D.N.Y. 1977).

82. Leasewell, Ltd. v. Jake Shelton Ford, Inc., 423 F. Supp. 1011 (S.D. W.Va. 1976).

83. The Bremen v. Zapata Off-Shore Co., 407 U.S. 1 (1972). 
cases lies completely outside of conflicts law. There are many situations in which it does not make sense to struggle over the question of which state's law to apply. Airborne collisions of commercial passenger planes illustrate the problem vividly. Midair crashes may occur close to state lines so that it difficult to determine where, jurisdictionally, particular events occurred, and the location if determined may have little relevance to the interests affected by the crash. ${ }^{84}$ The persons affected may be residents of 20 or 50 different states, flying to and from a score of different places, on tickets purchased in a dozen different states or foreign nations. Air travel is in interstate or international commerce, and what is needed is national law applicable to all such claims to which the laws of the United States may properly be applied. It is federal substantive law, not conflicts law, that is needed.

The Federal Employers Liability $\mathrm{Act}^{85}$ took over the field of railroad employee injuries, a field which previously gave rise to much state choice-of-law litigation. Several other federal enactments have laid down nationwide rules to govern interstate transactions that formerly fell to state conflicts law. A federal statute prescribing all the legal consequences of air crashes is conceivable, but not presently a matter of major concern before the Congress. Nor are air crash cases the only ones for which national substantive law is needed.

Federal common law, in the absence of statutes, is beginning to provide the answer. In Kohr $v$. Allegheny Airlines, Inc. ${ }^{86}$ the question had to do with claims for contribution and indemnity between joint tortfeasors some of whom had paid off liabilities arising out of an Indiana midair collision. Indiana law allowed no contribution between tortfeasors. The Seventh Circuit concluded that federal common law, previously unstated, allows contribution on a comparative negligence basis, and governed the rights of the parties. This was an ideal decision. Interstate air travel has small relevance to state lines. National law governing it is appropriate not only with reference to claims between tortfeasors but to the claims of injured persons, including passengers, and their survivors. The federal common law rule announced in $K o h r$, concerning contribution and indemnity, was a wise and enlightened one, and it may be expected that federal substantive rules on other issues will be comparably sound. New federal common law to govern a number of other essentially national matters, eliminating state choice-of-law litigation accord-

84. See, e.g., In re Aircrash Disaster at Boston, Mass., July 31, 1973, 399 F. Supp. 1106 (D. Mass. 1975); In re Paris Air Crash of March 3, 1974, 399 F. Supp. 732 (C.D. Cal. 1975) (203 separate actions). See also Note, Air Crash Litigation: Disaster in the Courts, 7 Sw. U. L. Rev. 661 (1975), (foreword by the judge who sat on the Paris air crash cases).

85. 45 U.S.C. $\$ \S 51-60(1970)$.

86. 504 F.2d 400 (7th Cir. 1974), noted in 28 VAND. L. Rev. 621 (1975). Cf. Miree v. DeKalb Co., Ga., _ U.S. __ 97 S. Ct. 2490 (1977) (federal common law held not applicable). See also Haller, Death in the Air: Federal Regulation of Tort Liability a Must, 51 A.B.A.J. 382 (1968); Note, The Case for a Federal Common Law of Aircraft Disaster Litigation, 51 N.Y.U. L. REv. 231 (1976). 
ingly, is both desirable and inevitable. ${ }^{87}$ That, however, is not a part of conflicts law, but rather an escape from conflicts law.

In fact, one trend in American choice-of-law decision appears to be a kind of escape from conflicts law, or at least from the multiplicity of academic theory that clusters about and mystifies conflicts law. No court can in a single case follow all the theories that are currently proposed, but it can agree with their general effect, which is that there are better ways of deciding choice-oflaw issues than under the old mechanical rules prescribed by Professor Beale and the first conflicts Restatement. Every one of the new proposals calls for decision based upon real reasons relevant to the functions of law in our society, as distinguished from decision based upon formulas merely. Some of the proposals call for less judicial honesty in stating the real reasons for decision than do others, and a theory which leaves room for discreet cover-up of some real reasons has lingering appeal for judges still tied to the notion that all law must consist of rules and formulas. But real reasons generally underlie all of the modern approaches.

It is easy to understand why the courts are running the approaches together. They relate to each other, and each has sustainable merits, yet there are too many of them, and some of them are subtle and call for fine distinctions. Busy judges have no time to study and master all of them, then choose among them. Some afford more flexibility than others. The personalities of proponents influence some courts. Courts are also avoiding conflicts issues when they can reasonably do so. Explanations are easy, but the fact is what is important. The fact is that most American courts today are moving to what they call "the" new law of conflict of laws. It is a conglomerate, and not a bad one.

In terms of location, this body of law is being lifted up by the courts to a well-watered plateau high above the sinkhole it once occupied. No location lasts forever, and there are vistas beyond the plateau, but it is a rest-stop now. ${ }^{88}$

87. Illinois v. City of Milwaukee, 406 U.S. 91 (1972) (federal common law of public nuisance); Shaw v. Garrison, 545 F.2d 980 (5th Cir. 1977) (survival of tort claim). Cf. Atkins v. Schmutz Mfg. Co., 435 F.2d 527 (4th Cir. 1970), cert. denied, 402 U.S. 932 (197!) (federal rule on tolling of statute of limitations).

88. For a comparable analysis, but from a different point of view, see Reese, Choice of Law in Torts and Cintiats and Directions for the Future, 16 Colvm. J. TRansnat'i Law 1 (1977). 